\title{
Inclusion of kaolin in the feed of Japanese quails during the production phase
}

\author{
Inclusión de caolín en el alimento de codornices japonesas durante la fase de producción \\ Inclusão de caulim na alimentação de codornas japonesas durante a fase de produção
}

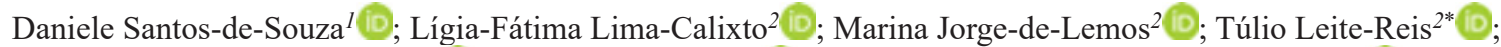

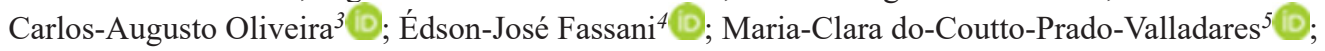

Felipe-Dilelis de-Resende-Sousa ${ }^{6}$.

\footnotetext{
${ }^{1}$ Animal Science, Universidade Estadual de São Paulo (UNESP), Botucatu, Brasil.

${ }^{2}$ Department of Animal Production, Universidade Federal Rural do Rio de Janeiro (UFRRJ), Seropédica, Brasil.

${ }^{3}$ Department of Animal Reproduction and Evaluation, Universidade Federal Rural do Rio de Janeiro (UFRRJ), Seropédica, Brasil.

${ }^{4}$ Universidade Federral de Lavras (UFLA), Lavras, Brasil.

${ }^{5}$ Animal Science, Universidade Federal Rural do Rio de Janeiro UFRRJ, Seropédica, Brasil.

${ }^{6}$ Bromatology Laboratory, Universidade Federal Rural do Rio de Janeiro (UFRRJ), Seropédica, Brasil.
}

Received: November 17, 2017; accepted: April 30, 2019

To cite this article:

Santos de Souza D, Lima-Calixto LF, Jorge de Lemos M, Leite-Reis T, Oliveira CA, Fassani EJ, Prado-Valladares MCdC, de Resende-Sousa FD. Inclusion of kaolin in the feed of Japanese quails during the production phase. Rev Colomb Cienc Pecu 2019; 32(4): 274-284. https://doi.org/10.17533/udea.rccp.v32n4a03

(cc) BY-NC-SA This work is licensed under a Creative Commons Attribution-NonCommercial-ShareAlike 4.0 International License. 


\section{Abstract}

Background: Kaolin may improve quail performance by maintaining intestinal integrity and improving nutrient absorption. Objective: To evaluate the overall performance, egg quality, moisture, nitrogen and calcium content in the excreta, intestinal morphology and financial analysis of kaolin in Japanese quail feed during the production phase. Methods: A total of 192 Japanese quails, distributed in a completely randomized design with four treatments and six repetitions with eight birds each, were used. Kaolin levels added to the diet were 0, 1.5, 3.0, and 4.5\%. Results: Kaolin reduced feed consumption. Additionally, egg production, feed conversion and viability increased. Moisture, nitrogen and calcium in the excreta decreased. Height and width of the intestinal villi increased with increasing levels of kaolin in the diet. Kaolin had no effect on egg quality. Inclusion level of 1.5\% kaolin allowed for greater economic gains. Conclusion: Kaolin improved performance, intestinal morphology, and reduced the moisture, nitrogen and calcium contents in the excreta. Egg quality remained unchanged with the addition of kaolin, and the best economic response resulted with the addition $1.5 \%$ kaolin.

Key words: clay; Coturnix coturnix japonica; egg quality; feed additive; nutrition; nutrient absorption; intestinal morphology; intestinal villi; Japanese quail; kaolin; performance.

\section{Resumen}

Antecedentes: El caolín puede mejorar el rendimiento de la codorniz al mantener la integridad intestinal y una mayor absorción de nutrientes. Objetivo: Evaluar el rendimiento general, calidad del huevo, humedad, contenido de nitrógeno y calcio en la excreta, morfología intestinal, y realizar un análisis financiero de la inclusion de caolín en el alimento de codorniz japonésa durante la fase de producción. Métodos: Se utilizaron un total de 192 codornices japonesas, distribuidas en un diseño completamente al azar con cuatro tratamientos y seis repeticiones con ocho aves cada una. Los niveles de caolín agregado a la dieta fueron $0 ; 1,5 ; 3,0 ;$ y 4,5\%. Resultados: El caolin redujo el consumo de alimento, hubo una mejora en el porcentaje de huevos producidos, la conversión del alimento y la viabilidad, Los niveles de humedad, nitrógeno y calcio en la excreta disminuyeron, la altura y el ancho de las vellosidades intestinales aumentaron con la inclusión de niveles crecientes de caolín. No hubo efecto sobre la calidad del huevo. Los niveles de inclusión de 1,5\% de caolín permitieron mayores ganancias económicas. Conclusión: El caolín mejoró el rendimiento, la morfología intestinal y redujo los contenidos de humedad, nitrógeno y calcio en las excretas. La calidad de los huevos producidos se mantuvo sin cambios con la adición de diferentes niveles de caolín, y el mejor nivel de inclusion de caolín -según el análisis económico- fue de 1,5\%.

Palabras clave: absorción de nutrientes; aditivo alimenticio; arcilla; calidad del huevo; caolín; codorniz; Coturnix coturnix japonica; morfología intestinal; nutrición; rendimiento; vellosidades intestinales.

\section{Resumo}

Antecedentes: O caulim pode melhorar o desempenho de codornas mantendo a integridade intestinal e maior absorção de nutrientes. Objetivo: Avaliar o desempenho global, a qualidade do ovo, a umidade, o teor de nitrogênio e cálcio na excreta, a morfologia intestinal e a análise financeira do caulim em codornas japonesas durante a fase de produção. Métodos: Foram utilizadas 192 codornas japonesas, distribuídas em delineamento inteiramente casualizado, com quatro tratamentos e seis repetições, com oito aves cada. Os níveis de caulim adicionados à dieta foram $0 ; 1,5 ; 3,0 ; 4,5 \%$. Resultados: O consumo de ração foi reduzido, houve melhora na porcentagem de ovos produzidos, conversão alimentar e viabilidade, os níveis de umidade, nitrogênio e cálcio nas excretas diminuíram, a altura e a largura das vilosidades intestinais aumentaram com a inclusão de níveis crescentes de caulim. Não houve efeito na qualidade do ovo. Os níveis de inclusão de 1,5\% de caulim permitiram maiores ganhos econômicos. Conclusão: O caulim melhorou o desempenho, a morfologia intestinal e reduziu os teores de umidade, nitrogênio e cálcio na excreta. A qualidade dos ovos produzidos permaneceu inalterada com a adição de diferentes níveis de caulim, e o melhor nível de caulim, de acordo com a análise econômica, foi de 1,5\% como aditivo para as codornas japonesas.

Palavras-chaves: absorção de nutrientes; aditivo alimentar; análise financeira; argila; caulim; codornas; Coturnix coturnix japonica; desempenho; qualidade do ovo; morfologia intestinal; nutrição; vilosidade intestinal. 


\section{Introduction}

Kaolin is a clay used as an inert ingredient in the feed of birds. When used in high concentrations (above 1\% inclusion in feed) it may improve performance, intestinal integrity and egg quality. Kaolin can protect the intestinal mucosa and improve nutrient absorption due to its ability to reduce toxins that can cause injuries to the intestinal epithelium (Trckova et al., 2009; Owen et al., 2012). Moghaddam et al. (2008) observed an improvement in performance and egg quality after inclusion of clay (Zeolite) in the diet of laying hens. Kim et al. (2011) evaluating the effect of kaolin on egg quality and performance of laying hens did not detect improvements in egg quality; however, a significant reduction in feed intake and improvement in feed conversion were observed. Valladares et al. (2014) evaluated the effects of different kaolin levels in the feed of broilers, observing better quality of the litter.

When included at higher than recommended levels kaolin can function as an additive; however, the levels which may provide performance advantage are not fully understood. Therefore, the aim of the present study was to evaluate the overall performance, egg quality, moisture, nitrogen and calcium content in the excreta, intestinal morphology and provide a financial analysis of kaolin feed to Japanese quail during the production phase.

\section{Materials and methods}

\section{Ethical considerations}

This study was approved by Universidade Federal Rural do Rio de Janeiro (UFRRJ) Ethics committee for the use of animals in research (Comissão de Ética no Uso de Animais (CEUA) under Protocol no 23083.008446/201761.

\section{Location}

The experiment was conducted in the shed for quail research at Universidade Federal Rural do Rio de Janeiro (UFRRJ) in five periods of 21 days.

\section{Experimental design}

A total of 192 22-week-old Japanese quails were used.Quails were distributed in a completely randomized design with four treatments and six repetitions with eight birds each. The birds were raised in three tier pyramidal galvanized wire cages. Each cage $(100 \mathrm{~cm}$ front $\mathrm{x} 30 \mathrm{~cm}$ deep x $15 \mathrm{~cm}$ high) had a trough-type feeder, a nipple drinker and an egg collector. The light schedule used was 16 hours of light and 8 hours of dark. The treatments consisted of four diets: a reference diet without kaolin, and three diets with kaolin, supplemented at 1.5, 3.0, and 4.5\%. The diets were isoproteic, isoenergetic, and formulated to meet the nutritional requirements of Japanese quails in production phase, according to Rostagno et al. (2011).

The variables evaluated were: feed intake (FI), laying percentage, feed conversion per dozen eggs (FC), egg weight, Haugh units (HU), yolk index (YI), percentage of egg components (yolk, albumen and shell), shell thickness (ST), intestinal villi height, width, and crypt depth. Moisture, nitrogen and calcium in the excreta were evaluated. A financial analysis on the use of kaolin was carried out at the end of the experiment. An average was calculated to determine FI (g/bird/day) at the end of each 21days period. Egg quality evaluations were based on daily egg production every 21 days. Eighteen eggs were collected for three consecutive days from each of the four treatments, totaling 216 eggs. Haugh units was calculated using the formula proposed by Card and Nesheim (1966), $\mathrm{HU}=100 \log \left(\mathrm{H}+7.57-1.7 \mathrm{~W}^{0.37}\right)$, where $\mathrm{H}=$ height of the dense albumen $(\mathrm{mm})$ and $\mathrm{W}=\mathrm{egg}$ weight $(\mathrm{g})$. Yolk index was determined from yolk height and albumin diameter. A Mitutoyo analog caliper (Mitutoyo, Hiroshima, Japan) was used to take these measurements and dense albumen height. Yolk index was calculated as the ratio between yolk height and diameter (Sharp and Powell, 1930). To obtain egg components (\%), egg yolks were separated from the albumen, weighed on a digital scale (precision: $0.01 \mathrm{~g}$ ), and shells were rinsed to remove remnants of albumen and dried at room temperature for 24 
hours to obtain shell weight. Albumen weight was obtained by subtracting yolk and shell weights from egg weight. The ST was measured with an analog pressure micrometer after drying the samples. Thickness values were obtained from two readings in the equatorial zone of the shell fragments. The ST was obtained from the average of these two points.

At the end of the experiment, when the birds were 38 weeks of age, 24 birds ( 1 bird per replicate) were sacrificed by cervical dislocation for the collection of the small intestine and subsequent analysis of intestinal morphology according to the method described by Pelicano et al. (2005). Samples of approximately $2.0 \mathrm{~cm}$ were removed from the middle portion of the intestinal segments (duodenum, jejunum and ileum), then gut sections were fixed for 8 hours in Bouin liquid and then placed in $70 \%$ alcohol. These materials were sent to the histology laboratory where they were processed using a routine histological technique, which included dehydration, diaphanization, impregnation and paraffin embedding to obtain $5 \mu \mathrm{m}$-thick histological sections. The histological staining protocol by the Hematoxylin-Eosin technique (HE) was applied to the cuts to examine small bowel architecture using light microscopy. All histological sections were scanned and the images, magnified by 100, were analyzed under an Olympus BX 41 microscope (Olympus Corporation, Tokyo, Japan) coupled to a digital Nikon Coolpix 4300 camera (Nikon Corporation, Tokyo, Japan).

In the last five days of the experimental period, fecal samples were taken to determine moisture, nitrogen and calcium contents using the total collection method (Sibbald and Slinger, 1963). Samples were collected twice a day, at 7 am and at $6 \mathrm{pm}$ to avoid possible fermentation. This material was transferred to labeled plastic bags and stored in a freezer until the end of the collection period, when the excreta were thawed, homogenized and dried at $105{ }^{\circ} \mathrm{C}$ for a period of 72 hours. The methodology recommended by Kiehl (1985) was used to quantify moisture content in the excreta. Calcium and nitrogen in excreta were determined according to the methodologies described by Silva and Queiroz (2002).

\section{Financial analysis}

The financial analysis considered feed intake, egg production, feed conversion, cost of feed, sale price of eggs and the costs usually involved in quail production. The cost per kilo of feed considered the average price of ingredients: corn, soybean meal, limestone, dicalcium phosphate, soybean oil, salt, mineral and vitamin mixture, DL-methionine, L-lysine $\mathrm{HCl}$, choline chloride and kaolin (price in USD converted to BRL) in Rio de Janeiro state, Brazil. The Internal Rate of Return (IRR), Net Present Value (NPV) and Cost-Benefit of using kaolin in feed quail were calculated.

\section{Statistical analysis}

The results were submitted to analysis of variance and the effects of kaolin levels were estimated by analysis of the variables by linear and quadratic regression methods according to the best fit obtained for each variable.

\section{Results}

Kaolin inclusion in the feed resulted in a positive effect on quail performance $(p<0.05)$ (Table 1). 
Table 1. Performance of Japanese quails fed increasing levels of kaolin.

\begin{tabular}{|c|c|c|c|c|c|c|}
\hline \multirow{2}{*}{ Variables } & \multicolumn{4}{|c|}{ Kaolin level (\%) } & \multirow{2}{*}{ Regression } & \multirow{2}{*}{ CV $(\%)$} \\
\hline & 0.0 & 1.5 & 3.0 & 4.5 & & \\
\hline FI (g/bird/day) & 29.3 & 28.8 & 28.2 & 28.2 & $\mathrm{~L}^{*}$ & 7.35 \\
\hline Egg percentage & 87.8 & 92.7 & 92.7 & 93.7 & $\mathrm{~L}^{*}$ & 8.02 \\
\hline $\mathrm{FC} / \mathrm{dz}$ & 0.30 & 0.27 & 0.24 & 0.23 & $\mathrm{~L}^{*}$ & 6.17 \\
\hline Viability (\%) & 96 & 98 & 98 & 99 & $\mathrm{~L}^{*}$ & 6.47 \\
\hline
\end{tabular}

FI: feed intake (g/bird/day); \% of eggs: percentage of eggs produced; FC/dz: feed conversion per dozen eggs; ${ }^{*} \mathrm{~L}$ : linear effect $(\mathrm{p}<0.05)$; CV: coefficient of variation.

Egg weight, Haugh unit, yolk index, yolk, albumen and shell percentages, and eggshell $\mathrm{t}$ hickness were not affected $(\mathrm{p}>0.05)$ by increasing levels of kaolin in the feed (Table 2).

Table 2. Quality of eggs produced by Japanese quails fed different levels of kaolin.

\begin{tabular}{|c|c|c|c|c|c|c|}
\hline \multirow{2}{*}{ Variables } & \multicolumn{4}{|c|}{ Kaolin level (\%) } & \multirow{2}{*}{ Regression } & \multirow{2}{*}{$\begin{array}{l}\mathrm{CV} \\
(\%)\end{array}$} \\
\hline & 0.0 & 1.5 & 3.0 & 4.5 & & \\
\hline Egg weight (g) & 11.68 & 12.04 & 11.89 & 11.68 & $\mathrm{NS}^{*}$ & 5.27 \\
\hline HU & 89.91 & 90.09 & 90.61 & 90.15 & $\mathrm{NS}^{*}$ & 6.41 \\
\hline YI & 0.432 & 0.428 & 0.43 & 0.434 & $\mathrm{NS}^{*}$ & 4.92 \\
\hline Yolk (\%) & 31.85 & 31.73 & 32.30 & 32.41 & $\mathrm{NS}^{*}$ & 5.28 \\
\hline Albumen $(\%)$ & 58.78 & 58.98 & 58.26 & 58.19 & $\mathrm{NS}^{*}$ & 4.37 \\
\hline Shell (\%) & 9.37 & 9.29 & 9.44 & 9.40 & $\mathrm{NS}^{*}$ & 5.12 \\
\hline Shell thickness (mm) & 0.18 & 0.182 & 0.185 & 0.181 & $\mathrm{NS}^{*}$ & 6.86 \\
\hline
\end{tabular}

HU: Haugh unit; YI: yolk index;

${ }^{*} \mathrm{NS}$ - not significant ( $\left.\mathrm{p}>0.05\right)$; $\mathrm{CV}$ : coefficient of variation.

The moisture content (\%), calcium and nitrogen present in Japanese quail excreta was influenced $(\mathrm{p}<0.05)$ by increasing levels of kaolin in the diet (Table 3). Thus, as kaolin levels increased, $\mathrm{H}_{2} \mathrm{O}, \mathrm{Ca}$ and $\mathrm{N}_{2}$ levels decreased in a linear function.

Table 3. Humidity in the excreta and excretion of calcium and nitrogen of Japanese quails fed increasing levels of kaolin.

\begin{tabular}{|c|c|c|c|c|c|c|}
\hline \multirow{2}{*}{ Variables } & \multicolumn{4}{|c|}{ Kaolin level, \% } & \multirow{2}{*}{ Regression } & \multirow{2}{*}{$\begin{array}{l}\text { CV } \\
\%\end{array}$} \\
\hline & 0.0 & 1.5 & 3.0 & 4.5 & & \\
\hline Moisture (\%) & 79.56 & 77.91 & 78.02 & 77.20 & $\mathrm{~L}^{*}$ & 7.81 \\
\hline Calcium excreted $(\mathrm{g} / \mathrm{kg})$ & 55.27 & 49.72 & 41.53 & 38.75 & $\mathrm{~L}^{*}$ & 7.34 \\
\hline Nitrogen excreted (\%) & 7.81 & 7.76 & 7.42 & 7.45 & $\mathrm{~L}^{*}$ & 8.26 \\
\hline
\end{tabular}

${ }^{*} \mathrm{~L}$ : linear effect $(\mathrm{p}<0.05) ; \mathrm{CV}$ : coefficient of variation. 
Figures 1, 2 and 3 show the effect of increasing levels of kaolin on excreta moisture and calcium, and nitrogen excretion.

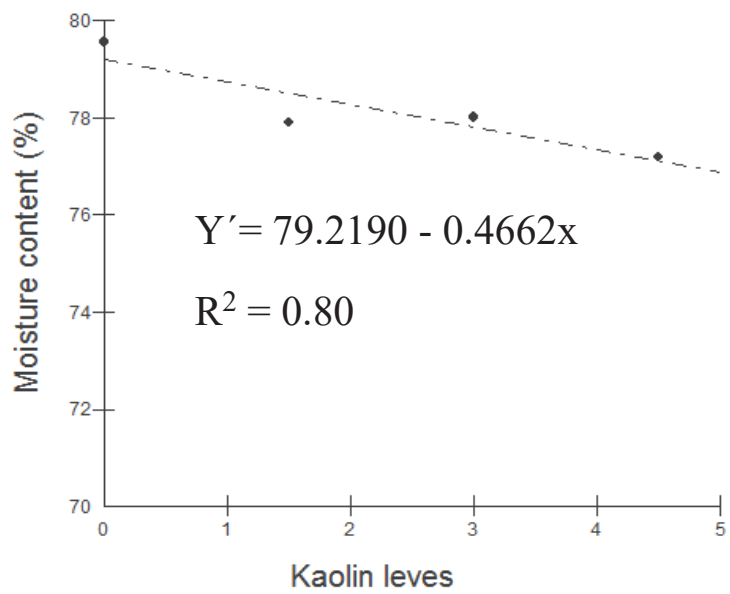

Figure 1. Moisture content in excreta according to kaolin levels in the diet of Japanese quails.

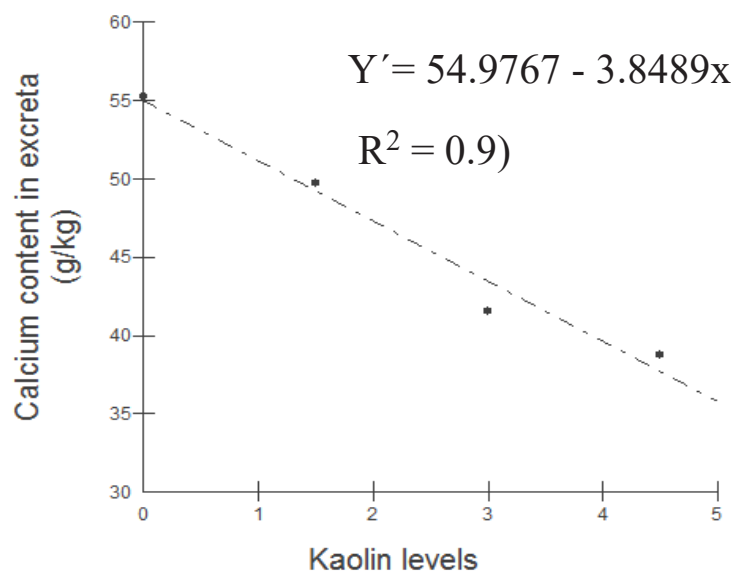

Figure 2. Calcium content in excreta according to kaolin levels in the diet of Japanese quails.

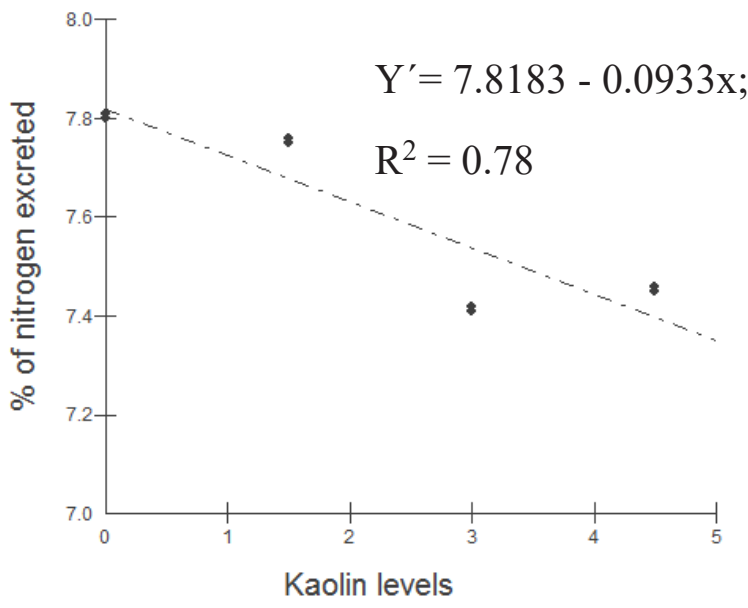

Figure 3. Percentage of nitrogen excreted according to kaolin levels in the diet of Japanese quails.

The height and width of intestinal villi (duodenum, jejunum and ileum) of quails were influenced $(\mathrm{p}<0.05)$ by increasing levels of kaolin in the feed. As kaolin levels increased, height and width of villi (duodenum, jejunum and ileum) increased, showing a linear trend (Figure 4).

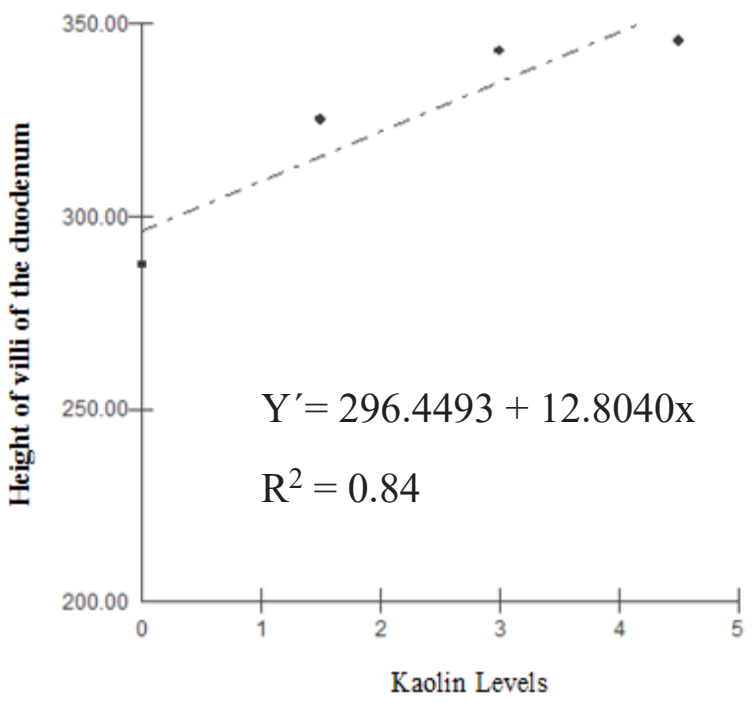



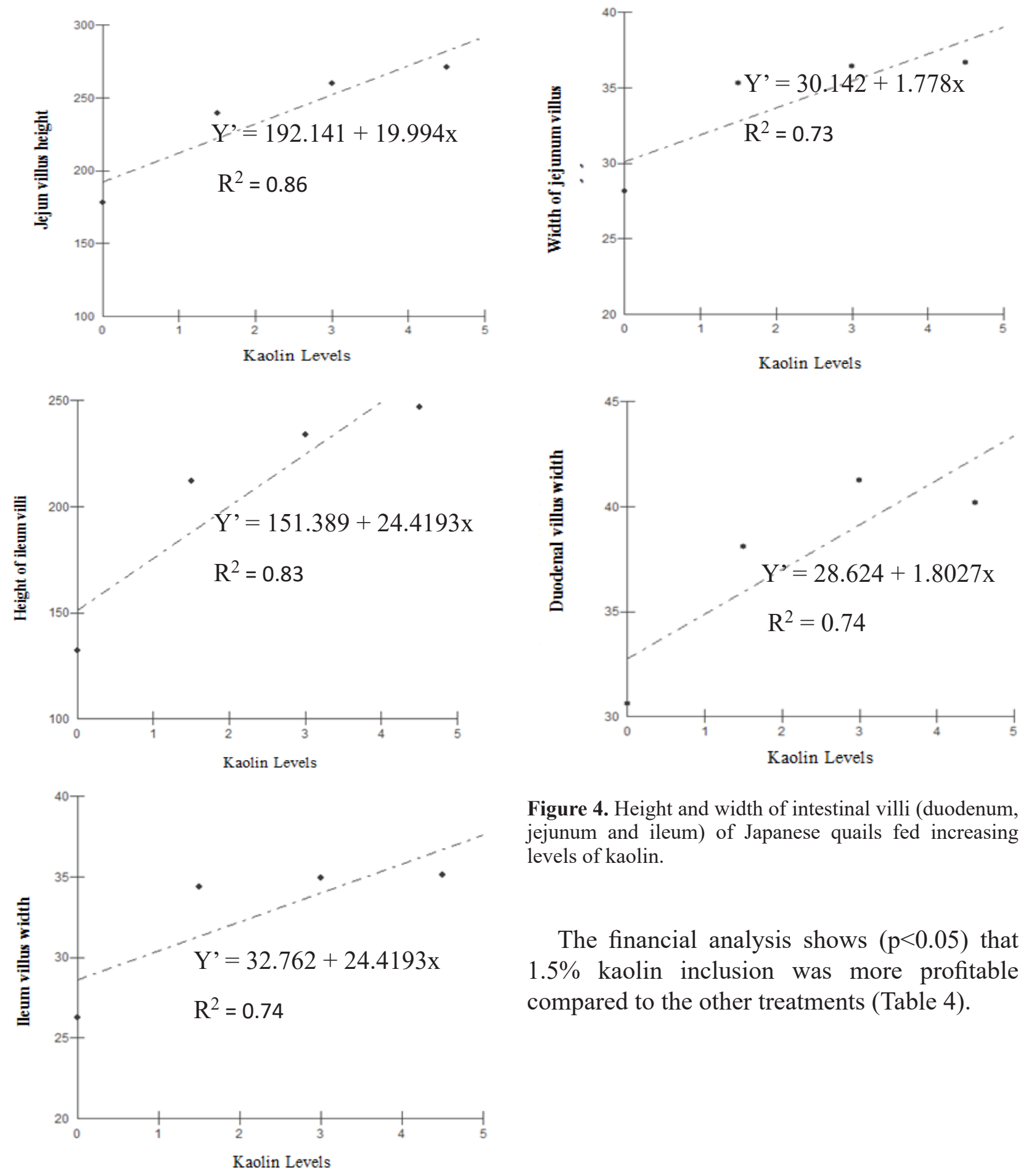

Figure 4. Height and width of intestinal villi (duodenum, jejunum and ileum) of Japanese quails fed increasing levels of kaolin.

The financial analysis shows $(\mathrm{p}<0.05)$ that $1.5 \%$ kaolin inclusion was more profitable compared to the other treatments (Table 4). 
Table 4. Financial analysis for increasing kaolin levels in the diet of Japanese quails in relation to profitability.

\begin{tabular}{ccccc}
\hline \multirow{2}{*}{ Variables } & \multicolumn{4}{c}{ Kaolin level, $\%$} \\
IRR & $\mathbf{0 . 0}$ & $\mathbf{1 . 5}$ & $\mathbf{3}$ & $\mathbf{4 . 5}$ \\
\cline { 2 - 5 } NPV & $11.6 \%$ & $16.8 \%$ & $15.4 \%$ & $14.3 \%$ \\
C / B & US 7,68 & US\$ 12,69 & US\$ 11,54 & US\$ 10,67 \\
\hline
\end{tabular}

IRR: internal rate of return; NPV: net present value; C/B: cost benefit.

\section{Discussion}

Feed intake was influenced $(\mathrm{p}<0.05)$ by increasing levels of kaolin in the feed. According to Safaeikatouli et al. (2012), the inclusion of clays in animal feed reduces the passage rate of digesta, improving digestibility, which causes birds to consume less feed to meet their nutritional requirements. Similar to the present study, Kim et al. (2011) also observed lower feed intake after inclusion of clay (kaolin) in the feed of laying hens.

Clay inclusion in the feed reduces the passage rate of digesta, improving nutrient digestibility, which may result in improved animal performance (Safaeikatouli et al., 2012). Moghaddam et al. (2008) also observed improvement in egg production after inclusion of clay (zeolite) in the feed of laying hens. Feed conversion followed the behavior observed in this study for feed intake and egg production. Similar to that seen in this study, Kim et al. (2011) when evaluating the addition of clay (kaolin) in the feed of laying hens also observed a significant improvement in feed conversion compared to the control group (without clay). Viability was also influenced $(\mathrm{p}<0.05)$ by the inclusion of increasing levels of kaolin in the diet. As kaolin level increased, quail viability increased. This was due to the improvement observed in performance caused by a better integrity of the intestinal tract. This result demonstrates an advantage of kaolin in quail viability since this species normally presents a high mortality rate; mainly in the final phase of production. Egg weight, Haugh unit, yolk index, percentage of albumin and shell, and eggshell thickness were kept at good quality regardless of the level of kaolin used $(\mathrm{p}>0.05)$. Similar to that observed in this study, Kim et al. (2011) also found no significant difference for variables of internal quality and eggshells produced by laying hens fed several levels of clay (kaolin).

Homer (1980) reported reduced water content in the excreta through an experiment with laying hens fed diets containing 2.5 and $5 \%$ bentonite compared to a control diet without clay. In winter, moisture content of excreta in the control treatment and treatment with $5 \%$ bentonite was 79.6 and $75.5 \%$, respectively, whereas in summer it was 81.5 and $76.3 \%$, respectively, indicating the efficiency of clay to control and reduce water content in excreta. In a study by Sellers et al. (1980) there was a significant reduction in excreta moisture of laying hens fed diets containing kaolin, without affecting, however, the performance and shell quality. The use of clays can prevent the occurrence of diarrhea due to its ability to absorb and retain ammonia (Evans and Ferrell, 1993), a function considered of extreme importance when it comes to reducing humidity in broiler and laying environments. This result is supported not only by reports mentioning the ability of clays to improve digestion efficiency and nutrient utilization (Trckova et al., 2009; Owen et al., 2012; Safaeikatouli et al., 2012), but also by the improved intestinal morphology observed in this study (Figure 8 ). Clays have the ability to absorb toxins that cause injuries to the intestinal 
epithelium thus protecting the intestinal mucosa and improving nutrient absorption, consequently the efficiency of energy and protein usage from the diet increases (Trckova et al., 2009; Owen et al., 2012). A major problem in poultry farming is ammonia volatilization and excessive moisture in the excreta, both harmful to the health and performance of birds. Ammonia becomes volatile after microbial decomposition of nitrogen compounds present in the waste, particularly uric acid excreted naturally by birds; therefore, the lower the nitrogen present in excreta, the lower the concentration of volatile ammonia in the aviaries (Schneider, 2017).

According to Macari et al. (2002), the absorptive capacity of the intestine is directly proportional to the size of the villi; birds with higher and wider villi may have better nutrients absorption. Clays can improve intestinal integrity through excretion of toxins produced by pathogenic microorganisms present in the gastrointestinal tract ( $\mathrm{Xu}$ et al., 2003). $\mathrm{Hu}$ et al. (2013) observed improvements in intestinal integrity, measured by villus height, after providing clay (montmonilonite) to broilers. Those researchers further stated that maintaining intestinal integrity is critical for proper functioning of epithelial cells and, consequently, for good animal performance. Depth of intestinal crypts was not affected $(p>0.05)$ by adding increasing levels of kaolin in the diet. Furlan et al., (2004) reported that increased crypt depth may indicate high proliferative cell activity that may typically occur as a response of the epithelium to some mucosa injury and seek to renew losses in the height of villi.

The IRR in relation to percentage of egg production was higher with the inclusion of $1.5 \%$ of kaolin in the diet than the other treatments. This rate expresses the profitability percentage of the project on the capital employed during its lifetime (Noronha, 1987; Hoji, 2006); therefore, the treatment that used $1.5 \%$ of kaolin showed a higher financial profitability compared to the other treatments. The net present value (NPV) presented positive values for all kaolin levels tested, and according to Noronha (1987), when the resulting NPV is positive the project is feasible, otherwise the project is not viable. According to Gouvea et al. (2014), the project that produces the highest NPV value is the most profitable option, thus the use of $1.5 \%$ of kaolin in the diet of Japanese quails, which led to the highest NPV (US \$12.69), showed higher profitability than the other treatments. The cost benefit analysis of kaolin in the feed of Japanese quail, demonstrated that the treatment with the addition of $1.5 \%$ of kaolin was the most financially viable in relation to the other treatments, because for every US $\$ 1.00$ invested in the production of quail eggs, there was a US\$1.12 return, while within the control treatment, in which kaolin was not used, for every US $\$ 1.00$ invested in the production of quail eggs, there was a US $\$ 1.08$ return; for the treatment with $3.0 \%$ of kaolin, for every US $\$ 1.00$ invested in the production of quail eggs, there was a US $\$ 1.11$ return, and for the treatment with $4.5 \%$ of kaolin for each US $\$ 1.00$ invested in the production of quail eggs there was a US \$1.10 return.

The inclusion of kaolin in the diet of Japanese quails during production, improves performance, intestinal morphology, reduces the moisture, calcium and nitrogen content in the excreta without affecting the quality of the eggs produced. The financial analysis indicated that $1.5 \%$ of kaolin as an additive in the feed of Japanese quails was the best alternative.

\section{Declarations}

\section{Conflicts of interest}

The authors declare they have no conflicts of interest with regard to the work presented in this report

\section{Author contributions}

Daniele Santos de Souza: Conception of the study, collected the data, wrote and reviewed.

Lígia-Fátima Lima-Calixto: Conception of the study, wrote and reviewed.

Marina Jorge de Lemos: Conception of the 
study, collected the data, statistical analysis, wrote and reviewed.

Túlio Leite-Reis: Conception of the study, statistical analysis, wrote and reviewed.

Carlos-Augusto Oliveira: Financial analysis.

Édson-José Fassani: Conception of the study and nutritional support.

Maria-Clara do Coutto- Prado-Valladares: Collected the data and laboratory analysis.

Felipe-Dilelis de Resende-Sousa: Collected the data and laboratory analysis.

\section{References}

Card LE, Nesheim MC. Poultry Production. Philadelphia: Lea \& Febiger; 1966. p.399.

Evans M, Ferrell DJ. Are there economic benefits to adding zeolits to poultry diets? Rec Adv In Ani Nutr In Austr 1993; p.303-316.

Furlan RL, Macari M, Luquetti BC. Como avaliar os efeitos do uso de prebióticos, probióticos e flora de exclusão competitiva. Proceedings of the Simpósio Técnico De Incubação, Matrizes de Corte e Nutrição; 2004; Balneário Camboriú, Brasil. 2004. https://www.researchgate.net/profile/Marcos Macari/publication/228600527 Como avaliar os efeitos do uso de prebioticos probioticos e flora de exclusao competitiva/ links/566eb9ff08aea0892c52a559.pdf

de Gouvea A, Gnoatto VJ, Silva ER L, Potrich M. Análise econômica da produção de Trichogramma pretiosum Riley em diferentes escalas. EntBra 2014; 7:41-47, https://www.periodico.ebras.bio.br/ojs/index. php/ebras/article/view/ebrasilis.v7i1.379

Hoji, M. Administração Financeira: uma abordagem pratica. 5nd ed. São Paulo (SP):

ATLAS; 2006.
Homer P, Shaible PJ. Poultry: Feeds and Nutrition. 2nd ed. Connecticut (USA); 1980. 6 $\mathrm{Hu}$ CH, Qian ZC, Song J, Luan ZS, Zuo AY. Effects of zinc oxide-montmorillonite hybrid on growth performance, intestinal structure, and function of broiler chicken. Poult Sci 2013; 92:143-150. https: 10.3382/PS.2012-02250

Kiehl EJ. Fertilizantes Orgânicos. 1985. p. 229269.

Kim JS, Jo JK, Yoon, SY, Yun, K, Kwon, IK, Chae, BJ. Effects of kaolin (natural ligneous clay) supplementation on performance and egg quality in laying hens. Jour of Ani Scie and Tech 2011; 53:133-138. https:10.5187/ JAST.2011.53.2.133

Macari M, Furlan RL, Gonzáles E. Ingestão de alimentos: Mecanismos regulatórios. Fisiologia aviária aplicada a frangos de corte. 2nd ed. Jaboticabal (SP): Funep/UNESP. Publishers, 2002.

Moghaddam HN, Jahanian R, Najafabadi HJ, Madaeni M. Influence of dietary zeolite supplementation on the performance and egg quality of laying hens fed varying levels of calcium and nonphytate phosphorus. J of Bio sci 2008; 8:328-334. http://www.docsdrive.com/ pdfs/ansinet/jbs/2008/328-334.pdf.

Noronha,

JF.

Projetos agropecuários: administração financeira, orçamento e viabilidade econômica. 2nd ed. São Paulo (SP): Editora Atlas S/A. 1987.

Owen OJ, Nodu MB, Dike UA, Ideozu HM. The effects of dietary kaolin (clay) as feed additive on the growth performance of broiler chickens. G J of Agri Sci 2012; 2:233-236.

https://pdfs.semanticscholar.org/30ed/ a6d724e97733940ed5197fde49f941a26a04.pdf.

Pelicano ERL, Souza PA, Souza HBA, Figueiredo DF, Boiago MM. Intestinal mucosa developmente in broiler chickens fed natural 
growth promotores. Revista Brasileira de Ciencia Avicola 2005; 7:221-229. https: 10.1590/S1516-635X2005000400005

Rostagno HS, Albino LFT, Donzele JL, Gomes PC, Oliveira RF, Lopes DC, Ferreira AS, Barreto SLT, Euclides RF. Tabelas brasileiras para aves e suínos. Composição de alimentos e exigências nutricionais. 3nd ed. Viçosa (MG): UFV Publishers; 2011.

Safaeikatouli M, Jafariahangari Y, Baharlouei A. An evaluation on the effects of dietary kaolin and zeolite on broilers blood parameters, T4, TSH and growth hormones. Pakist J of Nutri 2011; 10:233$237 . \quad$ https://www.researchgate.net/profile/ Mohsen Safaei2/publication/272822755 An Evaluation on the Effects of Dietary Kaolin and Zeolite on Broilers Blood Parameters T4 TSH and Growth Hormones/ links/54f03 $\overline{\mathrm{b}} 7 \mathrm{e} \overline{\mathrm{c}} \mathrm{cf} 25 \mathrm{f} \overline{7} 4 \mathrm{~d} 7 \overline{2} 47 \mathrm{ce} 2 . \mathrm{pdf}$.

Schneider AF, Yuri FM, Almeida DS, Roeder JVC, Xavier JS, Gewehr CE. Natural zeolites in broiler diet. Arq Bras de Med Vet e Zootec 2017; 69: 191-197. https: 10.1590/1678-41628717

Sellers RS, Herris GC, Waldroup PW. The effects of various dietary clays and fillers on the performance of broilers and laying hens. Poult Sci 1980; 59:1901- 1906. https: 10.3382/ ps.0591901

Sharp PF, Powell CK. Decrease in internal quality of hen's eggs during storage as by the yolk. Ind \& Eng Chem Res 1930; 22:909-910. https: 10.1021/ie50248a031
Sibbald JR, Slinger SJ. A biological assay for metabolizable energy in poultry feed ingredients together with findings which demonstrate some of the problems associated with the evaluation of fats. Poultry Science 1963; 42:313-325. https: $10.3382 /$ ps.0420313

Silva DJ, Queiroz AC. Análises de alimentos: métodos químicos e biológicos. 3nd ed. Viçosa (MG): Universidade Federal de Viçosa Publishers. 2002.

Trckova M, Vondruskova H, Zraly Z, Alexa P, HamrikJ, KummerV, PavlikI. The effect ofkaolin feeding on efficiency, health status and course of diarrhoeal infections caused by enterotoxigenic Escherichia coli strains in weaned piglets. Vet Med 2009; 54: 47-63. https://www.researchgate. net/profile/Ivo Pavlik/publication/237410569 The effect of kaolin feeding on efficiency health status and course of diarrhoeal infections caused by enterotoxigenic Escherichia coli strains in weaned piglets/ links/00b495277d $\overline{\mathrm{d}} 21822 \overline{\mathrm{e}} \mathrm{e} 000000 . \mathrm{pdf}$.

Valladares mcc, Filho CAS, Lemos MJ, Nak SY, Dias TFV, Alves OS, Souza DS, Calixto LFL. Umidade da cama de frangos de corte produzidos com rações contendo caulim. Proceedings of the 10th: XXVI Congresso Brasileiro de Zootecnia; 2014; Vitória, Brasil.

$\mathrm{Xu} \mathrm{ZR}, \mathrm{Hu} \mathrm{CH}$, Xia MS, Zhan XA, Wang MQ. Effects of dietary fructooligosaccharide on digestive enzyme activities, intestinal microflora and morphology of male broilers. Poult Sci 2003; 82:1030-1036. https: 10.1093/ $\mathrm{ps} / 82.6 .1030$ 